\title{
Fundamentals of Provincial Governance in Nepal's Federalism
}

\author{
Lecturer, Girdhari Subedi, PhD Scholar \\ Department of Political Science, Tribhuvan University, Prithvi \\ Narayan Campus, Pokhara, Nepal
}

\begin{abstract}
The objective of this article is to answer the state of provincial states and the challenges faced by them, and to show the constitutional provisions for coordination, cooperation and coexistence of interprovincial relations of Nepalese new federal set up. The provincial governments are facing lots of challenge including resource, proper policies, devolution of power and bureaucratic accountability and lack of intra-provincial coordination. The constitution stands on tri-pillar theory (cooperation, coexistence and coordination) to operate the holding together federalism in Nepal. In this article, an empirical facts and field observation of Gandaki Province have been analyzed. The writer argues that other provinces throughout the country have been facing the similar kinds of problems. During the writing, the facts were collected by inter and intrapersonal relations with the civil servants, provincial assembly members and various interaction programs with provincial stakeholders. But the core study area is Gandaki Province. The major finding of this study is that provincial cooperation and coordination is an essential factor to implementing federalism in Nepal. If the provinces failed to cooperate with federal government as well as intra-provincial government, federalism is hardly likely to sustain in Nepal.
\end{abstract}

Keywords: Constitution, cooperation, coordination, coexistenc, federalism.

\section{Introduction}

Initial debate on federalism in Nepali politics was brought into 
discourse after the advent of democracy in 1950. Leader of Terai Congress Bedananda Jha led a movement for federalism then ( Pokhrel and Pokhrel ;2014) After the restoration of parliamentary democracy in 1990, Nepal Sadbhabana Party leader Gajendra Narayan Singh raised the issues of federalism. The basic aspect of federalism is the division of state power and authority in between various levels of government (i.e. federal, provincial and local). In this federal system of governance, the political, administrative, economic and other functional responsibilities of the country are divided. The major basis of federalism is the diversity of units within a federation.

Countries that are demographically and geographically small or large, economically rich or poor have adopted the federal system. Like other countries, the state power in Nepal is divided into different layers of government -- federal, provincial and local (Anderson, 2008)

Nepal is an erstwhile a unitary state. The whole executive and legislative powers were vested within the central state. While introducing the Interim Constitution in February 2007, federal system was not stated in the constitution. However, with the protests from a section of political parties against the interim constitution, the first amendment to the interim constitution was made in March 2007.

Federalism was confirmed in a subsequent amendment in 2002 that ended the monarchy (Shurke, 2020; 5). Nepal has a different practice of governance from unitary to federal political system. Nepal's federalism is holding together federalism. The basic character of holding together federalism is cooperative federalism (Breen,2018). 


\section{Statement of the Problem}

Constitutionally, provincial governments have their own territory but in practice, they don't have own space to implement the programs and policies. Either the provincial government relies upon the local government or federal government's institutions. It has no right to collect the tax. It extracts only the service levy. Provincial governments have passed various laws but they are not embracing to the people hence, so the questions have been raised why provincial governments are not attracting the people. On the other hand, why federal parliament has not enacted necessary laws for provinces?

Provincial governments are under public criticism. They are not providing effective services delivery. They argue that federal government has not enacted laws to them but they have no inter-provincial coordination to implement their program and policies,

The constitution has established inter provincial council to deal with issues that have the potential of escalating in the contact of center province relations. It is the council of the ministers presides over the forum, and politically helps resolve issues. The pace of federalism has not been satisfactory to many stockholders. Stakeholders have officially and unofficially expressed their concerns in different forums.

The Constitution of Nepal, part 20 describe regarding the interrelations between federal, province and local level governments. The article 231 states about the legislative interrelations between federal and states. Similarly Article 232 says that the relations between the federal, states and local level shall be based on the principles of cooperation, coexistence and coordination. Likewise, Article 233 mentions that the state shall render assistance in the execution of legal provisions or judicial 
and administrative decisions or orders in another state.

This research aims to investigate how the provincial governments could enhance their relations to each other as the spirit of constitution and what types of laws have been passed by the provincial assembly to support federalism and what types of understanding is evolving among the provinces regarding federalism and how it will be more effective that province regarding federalism and how it will be more effective. There are different practices among the provinces while formulating laws and numbers of enacted laws are different on the other hand. But there are some common voices among the chief ministers that federal government is curtailing the rights of province governments.

\section{Objectives of the study}

The province governments are in a preliminary phase to execute the constitutional rights. The trust of an individual towards the province government is not that positive. The general public argues that this form of governance is a burden of the state while asking to make local government more powerful than the province governments.

This research aims to devolve into the existing challenges of province governments and how they are coordinating and collaborating jointly to face their challenges. The objectives of this article are to introduce Gandaki Province and to trace out the constitutional provision of cooperation, coordination and coexistence of provinces. The third is to explore the shortcomings of coordination and cooperation between federal and province government, and lastly to disseminate the decisions of a meeting of the chief ministers held in Pokhara to boost up coordination among the provinces. 


\section{Literature Review}

Nepal is the newest federal country in the world. The federal structure of Nepal is divided into three layers of government -- federal, provincial and local. Inter-provincial relations are becoming more prominent. Cameron and Simeon (2002) labeled this new intergovernmental development as 'collaborative federalism' which referred to a process by which national goals are not unilaterally decided by the federal government any more but were codetermined by the individual provinces in a number of different policy areas including internal trade, social policy, environmental policy. Such types of rights in our constitution are provided in schedule of the constitution. Powers among the distinct spheres of governments in a federal system is the ultimate reality. The division of powers implies the uniqueness and independence of different levels of government in the intergovernmental domain.

Opeskin (1998) simply refers to relations between central, regional and local governments that facilitate the realization of common objectives through cooperation. Provincial government and their relation however reflects that it is concerned with interactions and relations of various levels of governments influenced largely by the macro political system, socio-economic and geo-political diversities and how these can be harnessed to promote cooperation and integration without compromising their autonomy.

Federalism is a process of government of self-rule and shared rule.(Michael Burgess;2006) The Constitution of Nepal provides the equal right to all provinces under schedule 6 of constitution. Federalism is both a societal and an institutional phenomenon (Erk; 2008). Federalism denotes the constitutional/ institutional configuration of the political system. The formal division of 
political power between the federal and provincial government are not fully exercised by the provincial government due to lacking of law and other operational hindrances. On the other hand, there is an operational confusion of the rights between federal and provincial states. In this regard, this research will attempt to explore the ideas of relation in the formative phase of federal Nepal.

The new challenges of inter-provincial relations are as opposed to simply considering the constitutional and institutional constraints. Constitution provides a certain list of powers and rights to the province in schedule 6 that power will reflects by provincial institutions. A 'deliberative turn' injected into federalist scholarship could also widen our understanding of the function of intergovernmental relations within federal political systems as discursive modes other than 'hard bargaining'.

The country is on the way of institutionalizing federal democracy. There is also a growing concern that civic space to express citizens grievances is shrinking gradually in the new federal structure (Prakash Bhattarai, 2019) Its objective is to strengthen the province and local government. If provincial government is made strong by policies, the federal political system will be attractive and sustained. This article attempts to spell out coordination, cooperation and coexistence process of interprovincial acts to enhance federalism. Again, it will identify the nature and numbers of passed bills by provincial assembly and how the acts are enhancing inter-provincial relation among them and what kinds of challenges have surfaced in formative phase of federalism by the provincial assembly.

The principles of cooperative government and inter-provincial relations organize the interdependence of the three sphere of government in Nepal. The schedule of constitution allocates the 
powers, which are distributive and interrelated and place duty on the sphere of government to respect each other's powers, functions and institutions. This study also helps understand the understanding of provincial members regarding federalism. Federalism is a political system; establish to build stronger democratic institutions and its practices. Federalism is for power and justice. It makes people more vibrant to search for power and equal distribution of resources.

Following, the successful completion of the election of three spheres of government in 2017, Nepal entered into building a strong federal democratic system. Thus, it laid down the foundation of new political structure and administrative operation. The constitution has clearly mentioned the power and functions of the three layers of government in its schedule. The federal structure of Nepal is cooperative federalism. Only by passing policies by provincial assembly, enacted laws and bilaws also make cooperative and coordinative federalism.

\section{Methodology}

Primarily, this article is a product of direct observation of the researcher of Gandaki Provincial office of Pokhara .The researcher visited different ministers of this province to understand their views on province. Different KIIs were taken with Gandaki Province Policy and Planning Commission ViceChairman Dr. Giridhari Poudel, Chief Attorney of Gandaki Province Dr. Rajendra Ghimire and other officials. Similarly open-ended questionnaires were filled up with gazettedofficers from different ministries of Gandaki Province and Gandaki Province Assembly members Mayanath Adhikari, Man Bahadur Gurung and Dhananjay Dawadi. Similarly, focus group discussions and interaction were conducted on provincial policy and enacted laws and their implications with the civil society 
members and province assembly's parliamentarians. The writing of this article is not an individual perception of the writer. It was an empirical experience sharing of province-level officials.

\section{Gandaki Province}

The Constitution of Nepal promulgated on 20 September 2015 clearly states the making of the provinces in Schedule 4. The seven provinces were formed by grouping 77 districts. The current system of seven provinces replaced an earlier system where Nepal was divided into 14 Administrative Zones, which were grouped into five Development Regions.

Gandaki Province is stretched from north to south of Nepal. It consists of 11 districts. This province occupies 14.67 per cent $(21,974 \mathrm{Sq} \mathrm{km})$ of Nepal's total land. In terms of geography, this province has a plain land in Terai to 8,167 meter of Dhaulagiri Himalayan range. There is one metropolitan city, 26 municipalities, 85 rural municipalities and 759 wards, having 18 constituencies for the federal parliament and 36 constituencies for province assembly. According to the National Census of 2011 , the total households are 577,682 with a total population of $2,403,757$ in the province.

KhasAryas, Magars, Gurungs, and hill Dalits are the main ethnic groups that make up Gandaki Province. Hill Janajatis constitute the majority in the province with $39.3 \%$ of the total population. However, Magars and Gurungs are distinct ethnic group within hill Janajati and they make up $17.4 \%$ and $11.3 \%$, respectively. Therefore, KhasAryas with $36.1 \%$ of the province's total population turns out to be the largest ethnic group. Other hill Janajatis, which makes up 10.5\% are Thakalis, Bhujels, Darais, Chhantyals, Duras, Barhams and others. Hill Dalits are almost one-fifth of the total population with 17.6\%. Gandaki Province ranks the second in terms of the population of Dalits. As in 
the other parts of the country, relation among these different socio-cultural groups is defined by unequal power sharing and discrimination on the basis of caste, ethnicity and gender.

\section{Constitutional Provision Regarding Inter-provincial}

\section{Relation}

Federalism is a power sharing political system. The relationships between federal/province/local governments are associated with constitutional provision. The relations between federal, province and local governments as by constitution are on cooperative, coordinative \& co-existence principle. The article 57 of the Constitution of Nepal describes the distribution of state powers between the governments. As per the constitution, the power of the federal is vested on the matters enumerated in schedule 5, and such powers shall be exercised pursuant to this constitution and the local government federal law. Similarly the powers of the province are vested according to schedule 6 and 8 .

Similarly, article 58 of the Constitution of Nepal mentions the residual powers of the state, which will vest in federation. The article 58 says that the federal shall have power on any matter not enumerated in the federal list, state list, list of local level or concurrent list or on any matter which is not so specified in this constitution as to be exercised by any level. The two articles (Article 57 and 58) clearly mentioned that what sort of cooperation is needed among the governments and how the power has to be exercised by the governments.

Part 20, of the Constitution of Nepal is a major guideline to the federal state of Nepal. This part explains the interrelationship of tri-government. Article 231 of constitution mentioned the legislative interrelationship. This article 231 (1) states that the federal law may be made to be applicable to the whole of, or, 
if required, to any part of, the territory of Nepal. Similarly 231 (2) mentions that a state law may be made to be applicable to the whole of, or as required, to any part of the territory of the state. Likewise, all the provinces of Nepal may use the right to enact laws to enforce as determined by schedule 6 of the Constitution of Nepal. Article 231(3) states if two or more states make a request to the Government of Nepal to make laws on any matter enumerated in schedule-6, the Federal Parliament may make necessary laws. Such laws shall be applicable only to the concerned States.

Article 232 is a cornerstone of inter-provincial relation. Basically, cooperation, coordination and coexistence are three major principles of inter-provincial relations. These three principles are the key pillars of inter-provincial relations. According to this article, any province of Nepal shall assist to each other in areas to execute the legal provisions or judicial and administrative decisions or orders of another state. Such kinds of legal provisions or orders enforce mutual consensus between provinces. Secondly, the administrative decisions or orders can be issued by federal government, which is compulsory to obey by all the provincial governments. They assess the basic foundation of inter-provincial relations which are as follows;

\section{Cooperation}

Cooperative federalism advocates the decentralization of policy to the lower tiers of governments with the federal government's role limited to encouraging efficient agreements between jurisdictions.(Inman and Rubinfeld,1997) Cooperative federalism, also known as marble-cake federalism, is a concept of federalism in which federal, state and local governments interact cooperatively and collectively to resolve common issues, rather than making policies separately but 
more or less equally (such as the dual federalism of the 19thcentury United States) or clashing over a policy in a system dominated by the national government.

In general, cooperative federalism asserts that governmental power is not concentrated at any governmental level or in any agency. Instead, the national and state governments share power. For instance, bureaucratic agencies at the national and state level normally carry out governmental programs jointly. Because the governments' responsibilities are divided between many levels of government, citizens and organized interests have many access points to influence public policy.

The constitutional foundations of the cooperative model of federalism are threefold. First, the proponents of cooperative federalism rely on a broad interpretation of the supremacy of constitution. Although the term "cooperative federalism" was originated in the 1930's, the roots of cooperative federalism reach back to the Thomas Jefferson administration. During the nineteenth century, the national government used land grants to support a variety of state governmental programs such as higher education, veterans' benefits and transport infrastructure. The Swamp Lands Acts of 1849, 1850, and 1860 are a prime example of this strategy. Under the various versions of this law, Congress ceded millions of acres of federal wetlands to 15 interior and coastal states. The acreage was "reclaimed" by the states and sold, with the profits being used to fund flood control. This strategy was later used in the Morrill Act of 1862, which gave land grants to the states to help fund the creation of state colleges.

The model of cooperative federalism was expanded during Franklin D. Roosevelt's New Deal. The influence of the national government over social welfare policies continued 
after World War II and into the 1960's when Lyndon B. Johnson declared his War on Poverty. Johnson's efforts to expand this safety net are often referred to as "creative federalism."

A "rights revolution" during the late 1960's and 1970's extended the idea of cooperative federalism as the national government became involved in issues such as the environment, job safety, mental health, education and the rights of disabled individuals. As the national government shaped new public policies to deal with these issues, it relied on the states to implement a wide array of federally imposed mandates.

\section{Coexistence}

Coexistence is a status quo situation of the provincial government. The federal government have to always recognize the legislative and executive power of the province, similarly provincial governments must respect to each other in their governance capabilities. Coexistence maintains internal relation among the provincial government.

\section{Coordination}

Coordination enhances the relation among the provincial state and local governments. The Article 235 of the Constitution of Nepal has provided such right to the federal parliament to make necessary laws. Same way the federal government can form the state coordination committee and hold several meetings of the committee. Province has to work in coordination with and recommendation of local bodies.

\section{Horizontal relations and Inter-State Council:}

Federalism is a power sharing political system. The federal government shares it power to all provincial states either constitutionally or by delegating law. Nepal is facing basically 
four emerging challenges--constitution amendment, conflict over jurisdiction and resources of the provincial states, implementing federalism, inclusion and claim over multiple narratives (International Alert.,). As the same way the present Constitution of Nepal has made a provision of inter-state council under the chairmanship of the prime minister. The council is expected to settle political disputes between provinces. Article 234 states issues regarding inter- state council. The provisions of council include;

1. There shall be an Inter-State Council to settle political disputes arising between the Federal and a State and between States.

a) Prime Minister - Chairperson

b) Minister for Home Affairs of the Government of Nepal Member

c) Minister for Finance of the Government of Nepal - Member

d) Chief Ministers of the concerned States - Member

2. The Inter-State Council may meet as required.

3. In its meeting, the Inter-State Council may invite a Minister of the Government of Nepal and a Minister of the concerned State who is responsible for the matter of a dispute and a concerned expert.

4. The rules of procedures of the meeting of the Inter-State Council shall be as determined by the Council itself.

Inter-provincial cooperation is a major tool to bridging factor of inter-provincial relation. There is no any regulatory provision in horizontal relation among the provinces, except for Pokhara meeting of chief ministers and chief attorneys. They exchanged their experiences to each other but there is no any binding mechanisms to promote inter provincial relation. In absence of 
province, federalism is impossible. Effective and efficient service delivery system is the major role of provincial government.

The federal government has controlled both the resources and power of province governments. Human resource is a major factor to enhance the capacity of provincial government but competence \& capacitate manpower is not allocated by federal government to the provincial governments. Similarly provincial governments are facing lots of challenges to their delivery functions due to lack of civil servants. The reassessment of civil servants in the government mechanism is more essential. The placement of civil servants which is given by federal government is not appropriate. Nepal is exercising the federal political system although fifty three departments are still working under the 25 ministry of federal government.

Federal government always handles \& manages the bureaucracy. Federal bureaucracy and their ranks of hierarchy dominate to the provincial governments and bureaucracy. There is a huge gap in between federal civil service and provincial civil service in terms of their power, privilege and promotion. Federal bureaucracy is superior to provincial. Provincial civil servants feel that we are inferior and access less. The complexly of inferiority is declining the pace of provincial government. The centralized mindset of bureaucracy is a major obstacle of provincial government to coordinate and cooperate with inter-provincial relations. Similarly political leadership is a major obstacle to the federal government.

The province public service commission has not been formed yet. It has no right to appoint the officials. Hence, the career bureaucrats are always unwilling to work with at the province government, which has brought about a wrong impression of civil servants towards province government labeling it as an 
unable entity to deliver properly.

In Gandaki Province, only 1300 civil servants are working under the placement of provincial government. Now, we have 97,000 civil servants. Out of 97,000 civil servants, altogether 44,000 civil servants are adjusted in local government. That is the $45 \%$ of the total civil servants, among them only 14,000 civil servants are placed and adjusted in the provincial governments. (Devkota, 2020)

\section{Chief Ministers' meeting on Provincial Coordination}

The Pokhara meeting of the Chief Ministers of provincial governments on 10 September, 2018 was a major benchmark to execute federalism. The meeting was the first after the formation of provincial government and it was a step forward towards cooperation between provincial relations. The Chief Ministers' Pokhara meeting passed the major following resolutions:

a) Demand for a high-level political structure to execute federalism.

b) Management of civil servants.

c) Organization structure.

d) Classification of natural and fiscal resources allocation plan.

e) Development of wide \& diplomatic relations.

f) Prosecution of right to chief attorney.

g) Demanding necessary law for province.

h) Demanding the amendment of 7 Acts.

Major Challenges Among Federal, Province and Local Government

\section{Resource Collection and Distribution Problem}

The Article 57 of the Constitution of Nepal states regarding the 
distribution of state power but the federal, province and local governments are disputing and contradicting on the sphere of resource collection and distribution. Such kinds of issues can be addressed after the formation of National Natural Resources and Fiscal Commission in accordance to Article 251 of the Constitution of Nepal 2015. This problem will continue until the formation of commission.

\section{Inter-Province and Federal Province Relation}

Some members of provincial parliament assembly of Province No. 2 demanded that the province be declared "Special Province". Similarly Gandaki Province is disputing with the federal. There are some political, economic, cultural disputes arising between the federal and provincial states. The constitution ensures the inter-state council under the chairmanship of the prime minister. The council will resolve the disputing issues of the concerned province.

The constitution allocates power between federal province and local government although there is no clarity on the list of concurrent powers of federal, provincial and local governments. Hence, there is a problem to coordinate horizontally unlike in the past where the district development committee was collecting taxes on some resources including river-based mining. However, current constitution has not provided such rights to the District Coordination Committee in the new federal set up.

\section{The Need of Province Coordination Council}

The constitution has no any mandatory provision to form the province coordination council to settle down the differences of provincial conflicts. There are lots of differences in the natural resources including river-based mining, irrigation, drinking water supplies, forests and mine income revenue. 


\section{Lacks Human Resources}

Provinces are facing challenges for lack of efficient and skillful human resources. Most of the promoted-officers (who are not supposed to be very smart) are the chiefs of various branches and divisions of provincial government. There are some reservations on the part of quality service delivery from them. On the other hand, provincial public service commission is still in the making in absence of legal clarity. Similarly, provincial police bill is still not registered in the provincial parliament. Without provincial police act, it is too difficult to maintain peace and security in the province. Similarly, Local Administration Act 1970 is a hindrance to the provincial ministers since the province government has no right to enforce its decisions in regard to maintaining law and order.

\section{Dual Administration at Province}

In the provincial states, dual administration is still continuing due to lack of own institution and personnel staff. It also exists in local government. Chief District Officer is facilitating as the chief executive of the federal government in the district. The $\mathrm{CDO}$ is an agent of federal government in provincial states. Local Administration Act 1970 ensures enough power to exercise for the CDO.

\section{Effective and Efficient Operation of Provincial Institutions}

Provincial governments are creating their own new structure of administration even they are not well structured. The prime need of the province is to operate such institutions without any interference of the province government. While the new structure of administration will be effective and efficient, it will establish people's ownership. Provinces have to established their relevancy and ownership within their territory. 


\section{Required Federal Laws}

Provincial governments are exercising their rights and duties as given by the federal laws. The Schedule 4 of the Constitution of Nepal 2015 has mentioned power, role and responsibilities of the provinces. Province governments of Nepal are seeking basically police power, administrative power and financial power. The first meeting of the Chief Ministers of province held in Pokhara concluded with the demand of such power. But in practice, these rights and power are curtailed by federal government. Only 15 percent of total budget of Government of Nepal is allocated to all the provincial governments.

\section{Enacted Laws by Gandaki Province}

This research also aims to investigate into how the provincial governments could enhance their relations to each other as the spirit of constitution and what types of laws have been passed by the provincial assembly to facilitate federalism. There are different practices among the provinces while formulating laws and numbers of enacted laws are different. There are some common voices among the Chief Ministers that federal government is curtailing the rights of provincial governments.

\begin{tabular}{|l|l|l|}
\hline $\begin{array}{l}\text { S. } \\
\text { N. }\end{array}$ & Enacted laws by Gandaki Province & $\begin{array}{l}\text { Certified date } \\
\text { by Head of the } \\
\text { Gandaki Province }\end{array}$ \\
\hline 1 & $\begin{array}{l}\text { Some Public Documents of Province } \\
\text { Level Certification (Procedure) Act, } \\
2074\end{array}$ & \\
\hline 2 & $\begin{array}{l}\text { Act Relating on Financial Procedure } \\
\text { of Province No. 4, 2074 }\end{array}$ & $2075-1-5$ \\
\hline 3 & $\begin{array}{l}\text { Act Related on Privilege of Local } \\
\text { Level Officials and Members, 2074 }\end{array}$ & $2075-1-24$ \\
\hline
\end{tabular}




\begin{tabular}{|c|c|c|}
\hline 4 & $\begin{array}{l}\text { Acts Related on Remuneration and } \\
\text { Privileges of Ministers, } 2074\end{array}$ & $2075-1-24$ \\
\hline 5 & $\begin{array}{l}\text { Act Related on Remuneration and } \\
\text { Privileges of Provincial Assembly } \\
\text { Officials and Members, } 2074\end{array}$ & $2075-1-24$ \\
\hline 6 & $\begin{array}{l}\text { Act Related on } \\
\text { Appropriation, 2075 }\end{array}$ & $2075-1-30$ \\
\hline 7 & $\begin{array}{l}\text { Act Related on Assembly Operation } \\
\text { (Procedure) of Local Level, } 2075\end{array}$ & $2075-1-30$ \\
\hline 8 & $\begin{array}{l}\text { Act Related on Taxable and Non- } \\
\text { taxable Revenue, } 2075\end{array}$ & $2075-2-31$ \\
\hline 9 & $\begin{array}{l}\text { Act Relating on Province Finance } \\
\text { Management, } 2075\end{array}$ & $2075-2-31$ \\
\hline 10 & Act Relating on Finance, 2075 & $2075-3-27$ \\
\hline 11 & Act Relating on Appropriation, 2075 & $2075-327$ \\
\hline 12 & $\begin{array}{lcc}\text { Act Relating on } & \text { Province } \\
\text { Contingency Fund, } 2075 & \end{array}$ & $2075-3-27$ \\
\hline 13 & $\begin{array}{l}\text { Act Relating on Local Level Law } \\
\text { Making Process, } 2075\end{array}$ & $2075-3-27$ \\
\hline 14 & $\begin{array}{l}\text { Act Relating on Injection Service } \\
\text { (Operation and Management), } 2075\end{array}$ & $2075-3-27$ \\
\hline 15 & $\begin{array}{l}\text { Act Relating on Provincial Dairy } \\
\text { Development Board, } 2075\end{array}$ & $2075-4-30$ \\
\hline 16 & $\begin{array}{l}\text { Act Relating on Functions, Power } \\
\text { and Duties and Conditions of } \\
\text { Services and Facilities of Chief } \\
\text { Attorney, } 2075\end{array}$ & $2075-5-7$ \\
\hline 17 & $\begin{array}{l}\text { Act Regulating on Administrative } \\
\text { Procedure (regulation), } 2075\end{array}$ & $2075-6-8$ \\
\hline 18 & Act Relating on Cooperation, 2075 & $2075-10-27$ \\
\hline
\end{tabular}




\begin{tabular}{|l|l|l|}
\hline 19 & $\begin{array}{l}\text { Act Relating on Bar, Peepal, Sami } \\
\text { Ra Chautaro, 2075 }\end{array}$ & 2075-10-27 \\
\hline 20 & $\begin{array}{l}\text { Act Relating on Lake Protection and } \\
\text { Development Authority, 2075 }\end{array}$ & $2075-12-25$ \\
\hline 21 & $\begin{array}{l}\text { Act Relating on Province Industrial } \\
\text { Entrepreneurship, 2075 }\end{array}$ & $2075-12-25$ \\
\hline 22 & $\begin{array}{l}\text { Act Relating on Gandaki Province } \\
\text { Training Academy,2075 }\end{array}$ & 2075-12-25 \\
\hline 23 & $\begin{array}{l}\text { Act Relating on Province Good } \\
\text { Governance, 2075 }\end{array}$ & $2076-10-13$ \\
\hline
\end{tabular}

Source; Gandaki Province Act Collection, Part-I, 2018

This table shows that Gandaki Province has not enacted laws on horizontal and vertical relation as well as local governmental till September 15 of 2020. Gandaki Province has enacted 42 laws while some others are in pipeline. The competition among the province is evolving to enact the laws than its implication. Question is raised about the understanding regarding the provincial cooperation and coordination.

\section{Discussion}

Recently, the country has observed fifth anniversary of the promulgation of the Constitution of Nepal. Despite this achievement, many laws and bi-laws are yet to be formulated by the federal and provincial assembly to cooperate their relation with federal government and local governments. The provincial governments are in operation, they are still facing challenges of policies and public service delivery. Some bills and acts passed by the provincial assembly are limited only on paper and others are contradictory in nature. People and the stakeholders have been raising questions over the bills passed by the provincial assemblies. Public participation and consultation 
and parliamentary debates are the heart of formulating public policy. The role of provincial legislators, both opposition and the ruling parties, in parliamentary sessions are not effective as expected. Cooperation, coordination and coexistence are the founding pillars of sustaining new federalism. However, there is a certain level of mistrust and misunderstanding in practice between federal elites and provincial elites.

\section{Conclusion}

Gandaki province has passed its two years out of its five-year term. It has passed 25 Acts and more than 118 procedures and directives. Total 143 Acts, procedures and directives are prepared (an interview with Chief Minister P.S. Gurung in The Rising Nepal, 7 April, 2020). Ten Acts out of 25 are directly associated with the public and one is concerned with the chief attorney of Gandaki Province and only two Acts are relating on law making process of local level and law relating on local level assembly operation (procedure) acts are directly concerned with local governments. Law making process of this province is passive than six other provinces but this province initiated the meeting of the Chief Ministers which played a crucial role to building inter-provincial relations. It can be termed an exercise of constitutional right under Article 233(2). It is a major step towards cooperative and coordinative federalism. On the other hand, the first conference of chief attorney of provinces issued the 11-point Pokhara Declaration itself is a pace of execution of federalism.

Nepal's federalism is a cooperative, coordinative, collaborative and coexistence. It has lots of challenges and opportunities. It has centralized nature being holding together despite the fact that provinces of Nepal are competitive and conflicting to use their resources within their bordering territory. It is imperative 
to build the ownership of people over their patriotic feeling and self governance. If the three-tier governments are unwilling to coordinate and cooperate, federalism is not likely to sustain in an effective way.

The provincial governments have some confusion in their jurisdiction. The Schedule 6 has clearly mentioned the power of provinces but they have a lot of challenges to exercise power and policy due to limited funds and policies. Provincial governments have to cooperate and coordinate with local government and federal government to exercise the concurrent rights as given by Schedule 7 and 9 of the Constitution of Nepal. The departure of the Gandaki Province is the resolution of the first Chief Ministers' meeting but it is not possible without cooperation and coordination. The research is evolving how to coordinate and cooperate horizontally between the provinces.

\section{References}

Anderson, G. (2008). Federalism: An Introduction. New York: Oxford University Press.

Bhattarai, P. (2019). The New Federal Structure in Nepal: Challenges and Opportunities of Quality governance. EDP Network. Kathmandu Nepal: Centre for Social Change.

Breen, M. G. (2018). The Origin of Holding Together Federalism:

Nepal, Myanmar, And Sri Lanka". Publius: The Journal of Federalism, 48(1), 26-50.

Burgess, M. (2006). Comparative Federalism. USA: Routledge.

Cameron, D. \& Simon, R. (2002). Intergovernmental Relations in Canada: The Emergence of Collaborative Federalism. Publius: Journal of Federalism.

Devkota, K. L. \& Acharya, M. R. (2008). Federal Nepal:

The Provinces: Comparative Analysis of Economic and Administrative Data and Challenges. Kathmandu. 
Devkota, K. L. (2020). Inter-governmental Fiscal Relations in a Federal Nepal. USA: Georgia State University, Andrew Young School of Policy Studies.

Elazar, D. J. (1991). Exploring Federalism. USA. University of Alabama press.

Erk, J. (2008). Exploring Federalism: State, Society and Congruence in Austria, Belgium, Canada, Germany and Switzerland. London \& UK: Routledge.

Karki, B. \& Edrisinha, R. (2014). The Federalism Debate in Nepal. Kathmandu: United Nations Development Programme (UNDP) Support to Participatory Constitution Building in Nepal (SPCBN).

Opeskin, D. (1998). The Reform of Intergovernmental Fiscal relations in Developing and Emerging Market Economies .Washington DC: World Bank.

Pokhrel, R. \& Pokhrel, B. P. (2070 BS). Nepal Ma Sangiyata Ko Bahaas Yatikhasik Prithabhumi Tatha Sandarbha. In Raju Prasad Chapagain, edited Naya Sambidhan Ma Sanghiyata Sajha Adhikar ko Khoji. Kathmandu Nepal: Juri Nepal.

Inman, R. P., \& Daniel L. R. (1997). Rethinking Federalism. Journal of Economic Perspectives, 11(4), 43-64.

Sharma, R. (2019). Federal Disputes Settlement in Nepal India and USA. Delhi: Adroit publishers.

Suhrke, A. (2014). Restructuring The State: Federalist Dynamics in Nepal. USA:CMI,Chr Michelson Institute.

The Constitution of Nepal (2015). Kathmandu : Law Books Management Board. 